\title{
Antibody-Antigen Complex Formation with Immobilized Immunoglobulins
}

\author{
Willfried Schramm*† and Se-Hwan Paek* \\ *The University of Michigan, Reproductive Sciences Program and Bioengineering Program, 300 North Ingalls, \\ Ann Arbor, Michigan 48109; and †BioQuant, Inc., 1919 Green Road, \\ Ann Arbor, Michigan 48105
}

Received December 9, 1991

We have investigated the complex formation between an immobilized monoclonal antibody and antigens that differ in size about 50-fold. As a model system, we used an iodinated progesterone derivative and a progesterone-horseradish peroxidase conjugate as tracer and a monoclonal antibody as binding protein. The antibody was immobilized by four different methods: physical adsorption, chemical binding, and binding via protein $G$ in the absence or presence of a protective protein (gelatin). These investigations have shown that the performance of competitive immunoassays is determined by a combination of factors: (a) the relative size of the analyte and the tracer, (b) the antibody density on the solid matrix, (c) the method of immobilization of the antibody, and (d) the binding constants between antibodyanalyte and antibody-tracer. All of these interactions have to be considered in designing an optimal immunoassay. The smaller antigen can form a 3- to 35-fold higher maximal complex density than the larger antigen. Dose-response curves are less affected by the size of the tracer than by the binding constant with the antibody. A large enzyme tracer with a relatively low binding constant can, therefore, provide a more sensitive assay. On the other hand, the increase in complex density achieved with a smaller tracer yields a higher signal that in turn can provide a better signal-to-noise ratio in highly sensitive competitive solid-phase immunoassays. We have suggested a model for antibody immobilization that accounts for the interdependence of tracer size, complex formation, and antibody density. The methods described can be used to design and optimize immunoassays of predefined performance characteristics. The results are particularly useful for converting radioimmunoassays to enzyme immunoassays. 1992 Academic Press, Inc.

A general trend in the development of immunoassays is to replace radiolabeled derivatives of analytes with enzyme-labeled tracers. Certain analytical problems arise if radioimmunoassays for small molecules are converted into enzyme immunoassays. In the design of radioimmunoassays, the analyte and the radiolabeled derivative of the analyte are generally treated as if they were of similar size. This simplification is no longer possible in enzyme immunoassays; the analyte-enzyme conjugate is substantially larger than the native small analyte.

We have previously shown that in solid-phase enzyme immunoassays the small analyte diffuses faster and forms complexes with immobilized antibodies before the large analyte-enzyme tracer reaches the surface $(1,2)$. As a result, the equilibrium reactions for the analyte and the enzyme-labeled tracer in solid-phase assays are different. In the present communication, we compared the binding of a small antigen (radiolabeled derivative of progesterone) with that of an antigen that has the same epitope but a total molecular weight 50 -times larger (enzyme-labeled progesterone derivative). The accessibility to antibody binding sites and affinity constants as a function of immobilization procedure and antigen size was analyzed. We also studied the effect of antigen size on dose-response curves and signal yields. These investigations permitted us to expand on a model suggested by Matson and Little (3) for antibody-antigen complex formation with different sizes of antigens.

Complex formation with antigens is affected by the qualities of the immobilized antibody, which is determined by the method of immobilization. We have compared the binding properties of a monoclonal antibody that was immobilized both by physical adsorption and by chemical binding to a modified surface. In addition, we studied the same antibody immobilized in the presence and absence of a protective nonspecific protein (gelatin) to surfaces that contained protein G. Protein G binds selectively to the $F_{c}$ region of immunoglobulins and leaves the paratope free for complex formation with 
antigens (4). We found that the method of antibody immobilization affected complex formation with the small and the large antigen differently.

By using a monoclonal antibody as the uniform binding protein, and a small and a large antigen with the same epitope to this antibody, we were able to provide quantitative estimates on complex formation with antibody immobilized by different methods. Similar approaches may be used for designing optimal solid-phase immunoassays, particularly if the analyte differs substantially in size from the analyte-enzyme conjugate used for signal generation.

\section{MATERIALS AND METHODS}

\section{Materials}

Horseradish peroxidase (HRP ${ }^{1}$, type VI, 300 units/ mg solid; EC 1.11.1.7), 1,5-diaminopentane (cadaverine), poly-L-lysine hydrobromide $\left(M_{r} 421,000\right)$, and $3,3^{\prime}, 5,5^{\prime}$-tetramethylbenzidine (TMB) were purchased from Sigma (St. Louis, MO). Disuccinimidyl suberate was obtained from Pierce (Rockford, IL); CNBr-activated Sepharose 4B, was obtained from Pharmacia Fine Chemicals, Inc. (Piscataway, NJ); Bio Gel P-30 and P-60 were obtained from Bio-Rad (Richmond, CA); and Immulon II microtiter wells were obtained from Dynatech Inc. (Alexandria, VA). Progesterone derivatives were synthesized and purified by HPLC as described elsewhere (5): progesterone-11 $\alpha-N$-hydroxysuccinimide (P-NHS); progesterone-11 $\alpha$-hemisuccinyl-1,5diaminopentane (P-CAD) obtained by reacting P-NHS with cadaverine; and progesterone-11 $\alpha$-hemisuccinyl tyrosine methylester (P-TME).

Monoclonal antibodies. The following antibodies were produced in this laboratory from peritoneal ascites fluid of mice as described elsewhere (5): two antibodies to progesterone ( $\mathrm{P}-\mathrm{Ab})$, one with a high affinity constant ( $>K_{a}=1 \times 10^{10}$ liter $/ \mathrm{mol}$, see Fig. 3; BQ.1) and the other with a low affinity constant $\left(K_{a}=9.0 \times 10^{8}\right.$ liter/ $\mathrm{mol} ; 4 \mathrm{C} 10$ ); one antibody to urease, used as nonspecific antibody (NS-Ab) that does not bind progesterone and HRP. The antibody with the high affinity constant (BQ.1) was used to study the formation of the antibodyantigen binding complex. Nonspecific interaction was subtracted by using NS-Ab. The antibody with the low

\footnotetext{
${ }^{1}$ Abbreviations used: ${ }^{125} \mathrm{I}-\mathrm{P},{ }^{125} \mathrm{I}$-labeled progesterone; $\mathrm{CNBr}$, cyanogenbromide; HRP, horseradish peroxidase; NS-Ab, antibody nonspecific to progesterone and HRP (antibody to urease); P-Ab, antibody to progesterone; P-CAD, progesterone-11 $\alpha$-hemisuccinyl-1,5-diaminopentane; P-HRP, HRP with one progesterone ligand per enzyme molecule; P-NHS, progesterone-11 $\alpha$-hemisuccinyl $N$-hydroxysuccinimide; P-TME, progesterone-11 $\alpha$-hemisuccinyl tyrosine methylester; TMB , 3, $3^{\prime}, 5,5^{\prime}$-tetramethylbenzidine; IgC, immunoglobulin G.
}

affinity constant $(4 \mathrm{C} 10)$ was used to purify progesterone-HRP conjugates.

All antibodies were precipitated by ammonium sulfate twice, dialyzed, and redissolved to a concentration

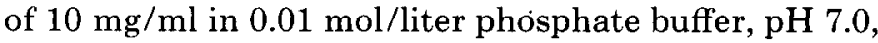
containing $0.14 \mathrm{~mol} / \mathrm{liter} \mathrm{NaCl}$ and $0.02 \%(\mathrm{w} / \mathrm{v})$ thimerosal (Buffer A). The final antibody solution was analyzed by using electrophoresis on acrylamide gel (6), and a single band for IgG was obtained. Aliquots of the solution were stored at $-20^{\circ} \mathrm{C}$.

${ }^{125}$ I-labeled reagents. P-Ab (BQ.1) was iodinated with carrier-free ${ }^{125}$ (NEN Research Products, DuPont Co., Wilmington, DE) by reduction with chloramine-T and subsequent termination of the reaction with sodium meta-bisulfite as described (7). Nonreacted iodine was eliminated by gel-exclusion chromatography (Bio-Gel P-60). The specific activity of the radiolabeled antibody was $1 \mathrm{Ci} / \mu \mathrm{mol}$, i.e., an average of about 0.5 iodine atoms was incorporated per antibody molecule.

The progesterone derivative P-TME was iodinated as described (5). We used the monoiodinated progesterone derivative $\left({ }^{125} \mathrm{I}-\mathrm{P}\right)$ for all experiments.

Progesterone-HRP conjugate. The progesteroneHRP was prepared as previously described (2). A conjugate was purified on an immunoaffinity column with the IgG to progesterone, $4 \mathrm{C} 10$, immobilized on $\mathrm{CNBr}$-activated Sepharose $4 \mathrm{~B}$ gel. The purified conjugate with one progesterone molecule bound to one HRP molecule ( $\mathrm{P}-$ HRP) was selected for all experiments, diluted with the same volume of Buffer A containing $0.1 \%(\mathrm{w} / \mathrm{v})$ gelatin (Buffer B), and stored at $-4^{\circ} \mathrm{C}$. The concentration of $\mathrm{P}-\mathrm{HRP}$ in solution was determined by comparing its activity in a solid-phase assay with standard concentrations of free HRP.

Substrate for HRP. The substrate solution for the determination of HRP activity contained $10 \mu \mathrm{l}$ of $3 \%$ (v/v) $\mathrm{H}_{2} \mathrm{O}_{2}$ in water, $100 \mu \mathrm{l}$ of $10 \mathrm{mg} / \mathrm{ml} \mathrm{TMB}$ in dimethyl sulfoxide, and $10 \mathrm{ml}$ of $0.05 \mathrm{~mol} /$ liter acetate buffer, $\mathrm{pH}$ 5.1.

\section{Immobilization of Antibody in Microtiter Wells}

Two monoclonal antibodies, P-Ab (BQ.1) and NS-Ab, were immobilized separately on the surface of microtiter wells by three different methods: (1) via protein $\mathrm{G}$, (2) by physical adsorption, and (3) by chemical binding of IgG to the modified microwell surface. All immobilizations were performed at room temperature.

Immobilization via protein $G$. Protein $\mathrm{G}$ was physically adsorbed to microwells by incubating overnight $200 \mu \mathrm{l}$ per well of a solution of $10 \mu \mathrm{g} / \mathrm{ml}(57 \mathrm{pmol}$ per well) in Buffer A. After discarding the solution and washing with deionized water, $250 \mu \mathrm{l}$ of $0.1 \%(\mathrm{v} / \mathrm{v})$ Tween 20 in Buffer B (Buffer C) was incubated for $3 \mathbf{h}$. After washing, antibody in Buffer B was incubated 
overnight. The wells were washed again and incubated with Buffer $\mathrm{C}$ for $3 \mathrm{~h}$. All plates were washed, filled with Buffer $\mathrm{B}$, and stored at $4^{\circ} \mathrm{C}$ in a sealed container to avoid evaporation. To prepare the immobilized antibody in the absence of other proteins, the same procedure was followed by using Buffer A without gelatin in the antibody preparation. Complex formation with antibody immobilized via protein $\mathrm{G}$ in the presence and absence of gelatin was studied to demonstrate the effect of gelatin under these conditions.

Physical adsorption. A solution of antibody in Buffer A ( $200 \mu \mathrm{l})$ was incubated in microwells overnight. After washing, the wells were incubated with $250 \mu$ l of Buffer $\mathrm{C}$ for $3 \mathrm{~h}$, washed, filled with Buffer $\mathrm{B}$ and stored at $4^{\circ} \mathrm{C}$ in a sealed container.

Chemical immobilization on polylysine coat. Antibody was bound to microwells, which were coated with polylysine, by oxidizing carbohydrate residues on the $F_{c}$ region of the immunoglobulin with $\mathrm{NaIO}_{4}(8)$ and reacting the resulting aldehyde groups with amino groups from polylysine. This reaction was performed in Buffer $A$ in the absence of any protective protein (e.g., gelatin). The resulting imide bonds were reduced with $\mathrm{NaCNBH}_{3}$ in Buffer $\mathrm{C}$ (2), and the wells were stored as described above.

\section{Determination of Surface Density and Nonspecific Binding}

The immobilization of antibody was quantitatively determined with preparations of nonlabeled IgG spiked with the iodinated antibody. To estimate the loss of antibody during preparation of stock solutions due to nonspecific binding, we prepared the IgG solutions by standard laboratory methods using disposable plastic pipettes. We incubated the final solutions $(1 \mathrm{ml})$ in borosilicate test tubes $(12 \times 75 \mathrm{~mm})$ for $1 \mathrm{~h}$, decanted the liquid for immobilization procedures (determination of surface density), and measured the residual radioactivity in the liquid with a $\gamma$-counter (GammaTrac 1290, Tm Analytic, Elk Grove Village, IL). The experiments were carried out in triplicate.

To determine the surface density of antibodies on polystyrene microwells with the four different immobilization procedures, we pipetted $200 \mu \mathrm{l}$ of the antibody stock solutions into microtiter wells and proceeded as described above (Immobilization of Antibody in Microtiter Wells). Loss of antibody to the pipette tips during the last transfer step was accounted for. The breakapart microwells were eventually dropped into $12 \times 75$ $\mathrm{mm}$ test tubes and counted for radioactivity. These experiments were carried out in quadruplicate.

\section{Complex Densities and Binding Constants}

The maximum complex densities and the binding constants between the antigens and the antibody were determined for each labeled antigen by Scatchard analysis (9). We incubated labeled progesterone $\left({ }^{125} \mathrm{I}-\mathrm{P}\right.$ or $\mathrm{P}-$ $\mathrm{HRP}$ ) diluted with Buffer $\mathrm{B}$ at different concentrations in microwells containing immobilized P-Ab for $2 \mathrm{~h}\left({ }^{125} \mathrm{I}-\right.$ $\mathrm{P})$ or $5 \mathrm{~h}(\mathrm{P}-\mathrm{HRP})$ on an orbital shaker. Thereafter, unbound tracer was separated by washing the microwells with deionized water. The concentration of bound antigen was determined by monitoring the $\gamma$-radiation of the radiolabeled derivative or by colorimetric detection of the enzyme activity as described elsewhere (10): (a) add substrate containing TMB as chromogen, (b) measure the developing color at the absorbance of 450 $\mathrm{nm}$ by spectrophotometry (microtiter plate reader; $\mathrm{Ti}$ tertek Multiscan, Type 310C; Eflab Oy, Finland), and (c) determine the concentration of the bound conjugate by means of a standard curve of a known amount of HRP (2). We subtracted nonspecific binding (measured in wells containing NS-Ab) for each data point. All estimations were performed in triplicate, binding constants were determined in two independent experiments, and the average was used for evaluation.

\section{Competitive Binding Curves}

We investigated competitive binding between ${ }^{125} \mathrm{I}-\mathrm{P}$ and $\mathrm{P}-\mathrm{HRP}$ in wells containing $\mathrm{P}-\mathrm{Ab}$ immobilized via protein $\mathrm{G}$ in the presence of gelatin. We used a microwell preparation with an antibody density of $0.32 \mathrm{fmol} /$ $\mathrm{mm}^{2}$. A constant concentration of P-HRP (100 $\mu \mathrm{l}$ per well of $142 \mathrm{fmol} / \mathrm{ml}$ ) and varying concentrations of ${ }^{125} \mathrm{I}$ $\mathrm{P}$ diluted in Buffer $\mathrm{B}$ were added to the wells (total volume $200 \mu \mathrm{l}$ ) and incubated for $5 \mathrm{~h}$ on an orbital shaker. After washing the wells, the signals from each labeled progesterone derivative were measured separately.

We performed dose-response curves with varying concentrations of native progesterone and each of the labeled progesterone derivatives in microwells with antibody immobilized via protein $\mathrm{G}$ in the presence of gelatin. The antibody density was $0.1 \mathrm{fmol} / \mathrm{mm}^{2}$. Standard solutions of progesterone were incubated with $100 \mu \mathrm{l}$ of either ${ }^{125} \mathrm{I}-\mathrm{P}(137 \mathrm{fmol} / \mathrm{ml})$ or P-HRP $(142 \mathrm{fmol} / \mathrm{ml})$ in a total volume of $200 \mu \mathrm{l}$ per well. The dose-response curves were analyzed by logit-log transformation (11). Each estimation was done in triplicate.

\section{Safety Considerations}

Experiments that included the use of radioisotopes were performed under the license and regulations of the Nuclear Regulatory Commission, according to the mandated requirements for handling, storing, monitoring, and disposal of radioactive isotopes.

\section{RESULTS AND DISCUSSION}

For these investigations, we have used immunoglobulin (a monoclonal antibody to progesterone) immobi- 

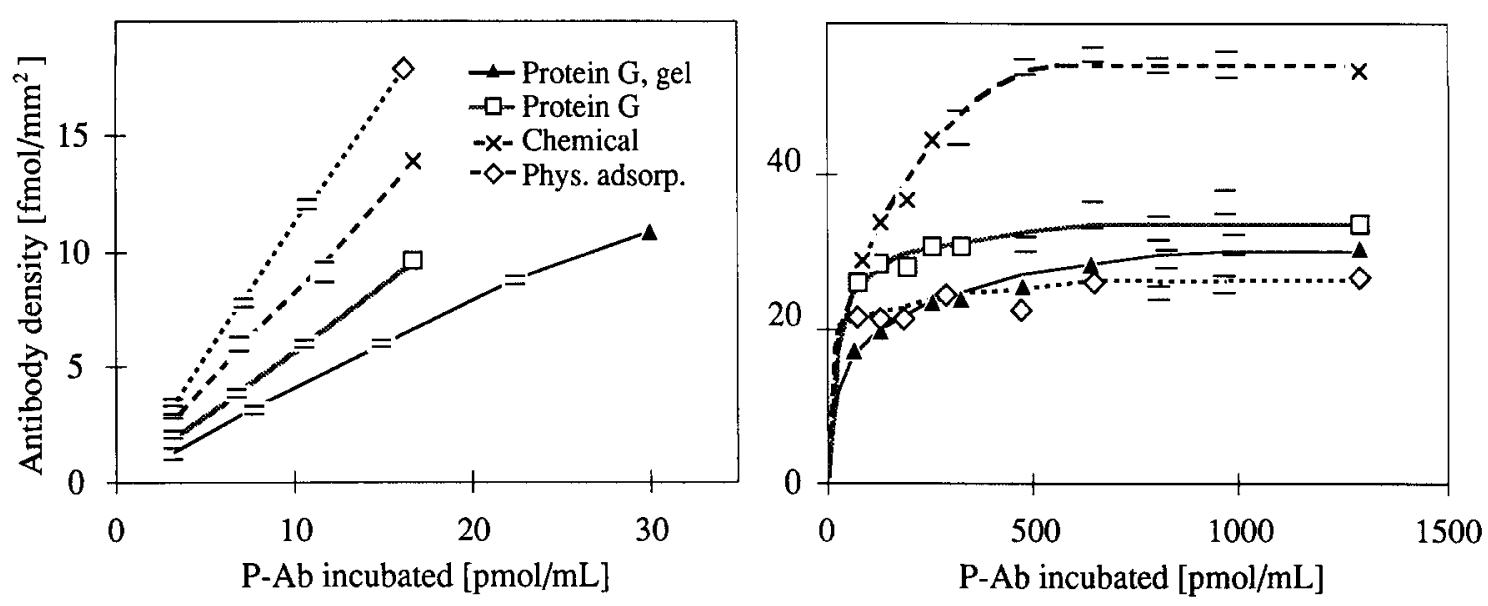

FIG. 1. Density of antibody immobilized by different methods to microwells as a function of antibody concentration in the incubation solution. Left, immobilization at the initial phase. Right, saturation curves for the adsorption of antibodies. Representative standard deviations are shown (derived from four estimates).

lized on the surface of microwells and studied the antibody-antigen formation with two different antigens: a radiolabeled derivative of progesterone and an enzymelabeled derivative of the steroid. For purposes of interpretation of the results, we will refer to both progesterone derivatives as antigens. The two antigens have an identical epitope (i.e., steroid hormone progesterone), which is recognized by the same paratope of the antibody. The antigens used in this study have molecular masses of 730 ( ${ }^{125} \mathrm{I}$-labeled progesterone tyrosine methylester) and 40,000 (12) (P-HRP). The P-HRP conjugate was purified by affinity chromatography and a fraction was sclected for these experiments that contained a uniform population of analyte-enzyme conjugate as shown by linear regression with Scatchard analysis. Likewise, by using a monoclonal antibody, we had a homogeneous binding protein available for studying antibody-antigen complex formation.

\section{Antibody Density}

The portion of antibody at low concentrations in the incubation medium that is captured on the surface decreases in the following order: physical adsorption $>$ chemical linking $>$ protein $\mathrm{G}>$ protein $\mathrm{G}$, gel (Fig. 1, left). This order changes at saturation (Fig. 1, right), which may simply represent different binding kinetics with the various methods. Chemical adsorption yields the highest density and the densities with antibodies immobilized by the other methods are similar.

If we incubated the antibody in a concentration greater than $500 \mathrm{pmol} / \mathrm{ml}$, the highest antibody densities obtained were (in $\mathrm{fmol} / \mathrm{mm}^{2} ; 157-\mathrm{mm}^{2}$ surface area per well when $200 \mu \mathrm{l}$ of solution is used) for: chemical immobilization, 54; protein G, 33; protein G, gel, 30; and physical adsorption, 25. Monomolecular layers of immunoglobulins immobilized by physical adsorption on sur- faces have been reported in the range of 17 and 100 $\mathrm{fmol} / \mathrm{mm}^{2}$ [17 (13), $\left.19(14), 50(15), 100(16,17)\right]$.

The differences reported by various groups can be explained, at least partially, by the fact that the macroscopic surface area is used as a basis for calculating antibody densities. The surface at the molecular level might be uneven and, therefore, larger. Under the conditions used in these experiments, we very likely have a monomolecular layer of $\mathrm{IgG}$ at about $30 \mathrm{fmol} / \mathrm{mm}^{2}$ at which $5 \%$ of the antibody incubated $(500 \mathrm{pmol} / \mathrm{ml})$ is used for the immobilization.

Two observations from studying the immobilization of antibody are noteworthy: (a) chemical immobilization yields twice the maximal antibody density than the other methods (Fig. 1, right), and (b) antibody immobilization in the presence of another protective protein can be used to provide antibody densities in the low range that are not achievable with traditional methods.

(a) Chemical immobilization on a polylysine coat. Two explanations are plausible without permitting us to rank their order for the high maximal antibody density with chemical immobilization: (i) the polylysine strands that cover the polystyrene surface extend, at least partially, distally to the surface area and provide, therefore, more attachment points for the IgG than does the surface alone; or (ii) IgG molecules are aggregated, forming an intermolecular lattice that contains more molecules than required for a monomolecular layer. In addition, antibody molecules may also bind to the polylysine coat mainly by charge interaction $(18,19)$. However, this interaction does not seem to provide a major contribution since we have found virtually no detectable dissociation of antibody in the presence of diluted plasma, chaotropic agents (urea), or high concentration of detergents (1\% Tween).

(b) Presence of protective protein. Using protein G for capturing IgG in the presence of gelatin, we have a 
TABLE 1

Antibody (P-Ab) Lost to Glass and Plastic Ware through Nonspecitic Binding during the Preparation of Stock Solutions (in Borosilicate Glass Tubes) if No Protective Protein (e.g., Gelatin) Was Present (Variation: $<3 \%$ in Triplicate Estimations)

\begin{tabular}{cc}
$\begin{array}{c}\text { P-Ab stock solution } \\
(\mathrm{pmol} / \mathrm{ml})\end{array}$ & $\begin{array}{c}\text { P-Ab lost } \\
(\%)\end{array}$ \\
\hline 3.2 & 65 \\
8.1 & 57 \\
16.1 & 53 \\
24.2 & 51 \\
32.3 & 45 \\
322.6 & 10 \\
\hline
\end{tabular}

better control on reproducible immobilization at low antibody densities. With this method, it is possible to prepare solid matrices with a wide range of antibody densities starting from $0.01 \mathrm{fmol} / \mathrm{mm}^{2}$ when $0.02 \mathrm{pmol} /$ $\mathrm{ml}$ antibody was incubated. In the absence of a protective protein such as gelatin, it is difficult to prepare antibody solutions in low concentrations $(<3 \mathrm{pmol} / \mathrm{ml}$ ) since the protein may be lost due to nonspecific binding on glass and plasticware (Table 1). We corrected for nonspecific binding in all the experiments described in this study, and the amount of antibody incubated (Fig. 1) reflects the concentration directly applied to the microwells.

\section{Complex Density}

The maximal complex density is higher for the smaller antigen than for the larger analyte-enzyme conjugate (Fig. 2, left vs right). Independent of the antigen size, the highest complex density is not much differ- ent among the immobilization methods. It is, however, reached at different antibody densities according to the immobilization methods in the following order: protein $\mathrm{G}$, gel $<$ protein $\mathrm{G}<$ chemical linking $<$ physical adsorption.

For all immobilization methods, the density of the antibody-antigen complex increases in proportion to antibody density until the complex density asymptotically approaches a limit, after which it remains constant. We have measured with P-HRP the highest maximal complex density (Fig. 2, right) before the surface reaches the highest antibody density at about $30 \mathrm{fmol} /$ $\mathrm{mm}^{2}$ (Fig. 1, right). The same is true for ${ }^{125} \mathrm{I}-\mathrm{P}$, protein $\mathrm{G}$ (gel), and physical adsorption.

The percentage of immobilized antibody that is available for binding the two antigens can vary in the different immobilization methods over a wide range (Fig. 2, numbers at curves). In comparison, Lin et al. (20) reported utilization of 1.3 to $3.5 \%$ (depending on the immobilization method) of the binding sites of immobilized antibodies (from polyclonal antiserum) for human IgG as antigen and 3 to $15 \%$ for digoxin as antigen (monoclonal antibody). In another study, reactive sites of antibodies bound to glass by different chemical reactions ranged from 15 to $100 \%$ (21) and all antibody binding sites remained active if IgG was immobilized through protein A.

\section{Binding Constants}

The binding constants between smaller antigen and antibodies immobilized by different methods were not much different but varied substantially for P-HRP. Binding constants with the larger antigen were lower for antibodies immobilized via protein $G$ and physical adsorption while the antibody immobilized on polyly-

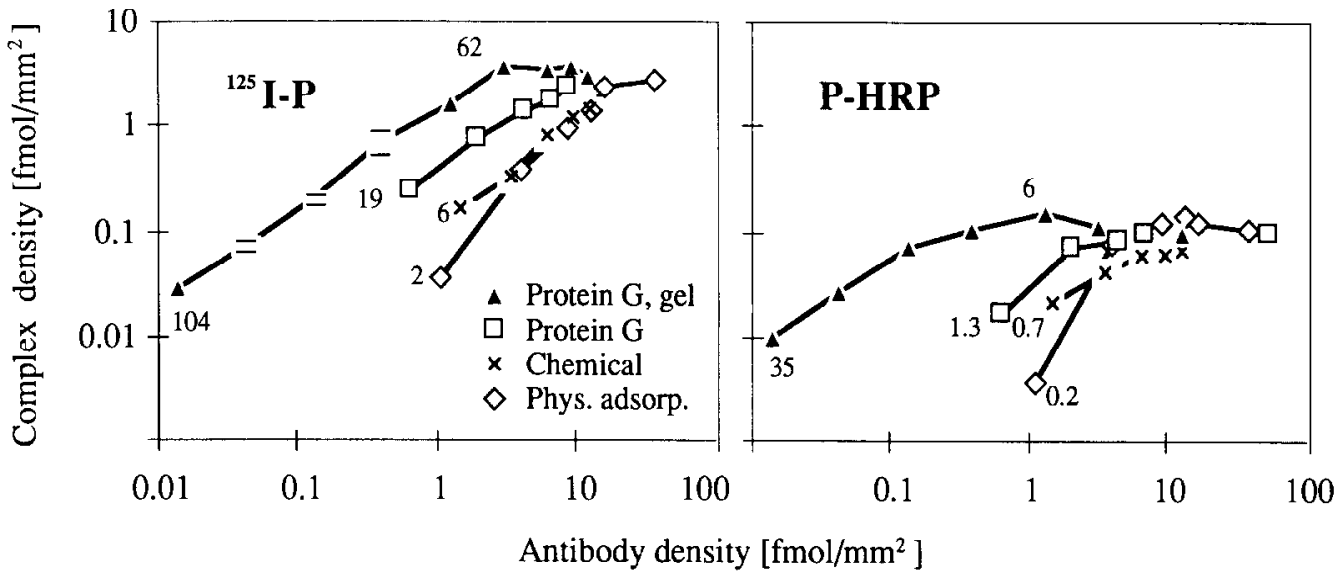

FIG. 2. Maximal antibody-antigen complex density with an antibody immobilized by different methods. A radiolabeled progesterone derivative (left) and a progesterone-HRP conjugate (right) were used as antigens. The percentage of antibody binding sites from the surface participating in complex formation (complex density/antibody binding sites) is shown for selected data points. Typical standard deviations (three estimates for each point) are shown for the curve protein G, gelatin. 

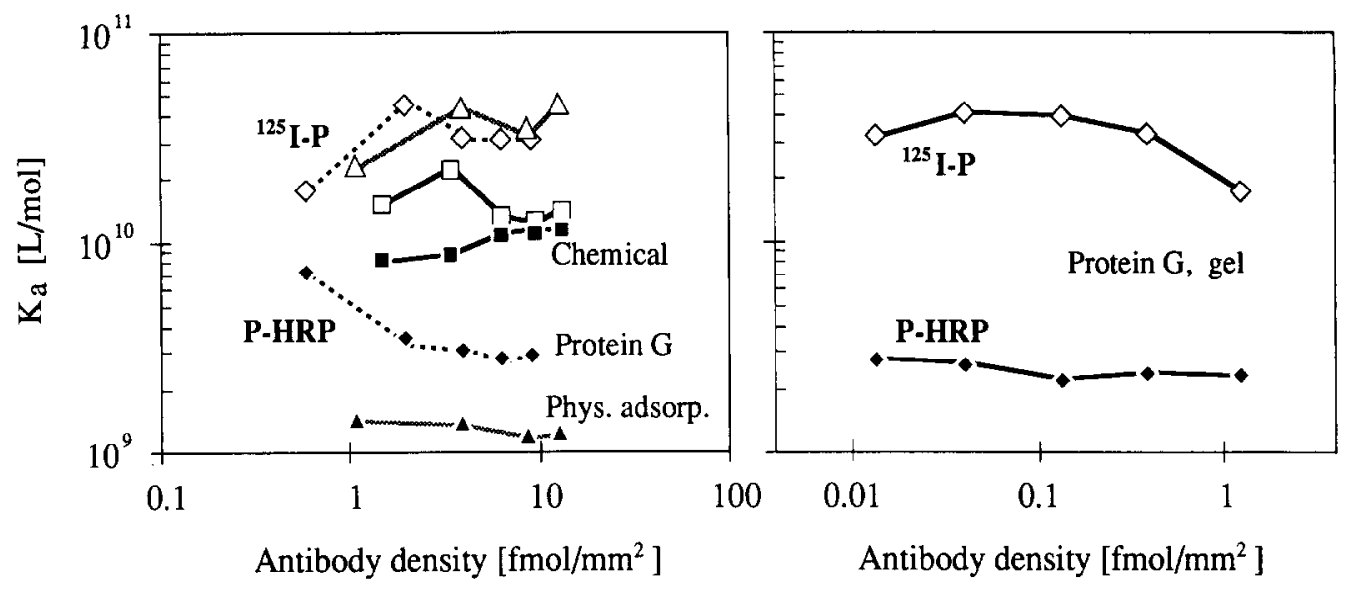

FIG. 3. Affinity constants, $K_{a}$, between a monoclonal antibody to progesterone immobilized by different methods and the iodinated derivative of progesterone ( ${ }^{125} \mathrm{I}-\mathrm{P}$, open symbols), and a progesterone-horseradish peroxidase conjugate (P-HRP, closed symbols) at different densitics of antibody on the surface of microwells. Right, with antibody immobilized via protein $G$, gel, binding constants at lower antibody densities ( $x$-axis) could be measured.

sine-treated surfaces bound both the large and the small antigen with approximately the same affinity (Fig. 3, left; note the logarithmic scale).

\section{Model for Complex Formation}

In analyzing the lower maximal complex formation with the P-HRP conjugate, one could assume that the large antigen masks, or covers up, several antibody binding sites on immobilized antibodies so that they are no longer available for binding of other conjugate molecules. This hypothesis cannot be supported because the dimensions of the HRP molecule are too small (12) that even under most ideal conditions of IgG immobilization (dense packing) only four paratopes of the IgG would be masked $(15,22,23)$.

With increasing antibody density on the surface of the solid matrix (Figs. 4A-D), large and small antigen have different accessibility as expressed in the ratio of maximal complex density at given antibody density (Fig. 5). We propose the following model for binding of antigens of different size to immobilized antibody.

Low antibody density, Stage A. At low antibody density, there is great potential for multiple interactions of the immunoglobulin with the surface and the paratope of the immunoglobulin might not be accessible to the large P-HRP conjugate. In Fig. 4A, we have symbolized one antibody in the side-on configuration (16) and another immobilized flat to the surface. Antibody binding sites are less accessible to the larger antigen and, with antibody attached at multiple points on the surface, they may not even be accessible to the smaller antigen. For example, only $2 \%$ of binding sites of immobilized antibody can form complexes with the radiolabeled antigen if the IgG is adsorbed to the surface by physical immobilization (Fig. 2, left). At this stage, the limited access of binding sites to the larger antigen (expressed in the ratio small/large antigen; Fig. 5, left, A) does not seem to be caused by crowding of antibody molecules due to limited surface area.

Increased antibody density, Stage B. Upon increasing antibody density, less free surface area becomes available for the IgG molecules to attach to, and more IgG molecules expose their paratopes (Fig. 4B). Consequently, binding becomes easier for the large antigen and the ratio of small over large antigen decreases (Fig. $5 B)$. For the immobilization of IgG via protein $G$ in the

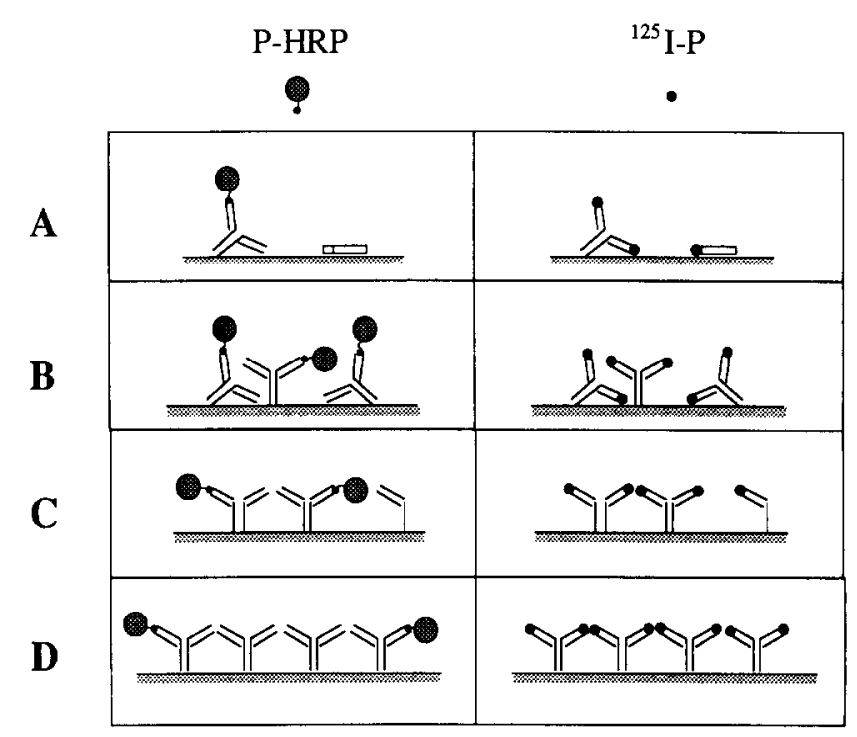

FIG. 4. Models of antibody-antigen complex formation for $\mathrm{P}-$ HRP and ${ }^{125}$ I-P at different antibody densities on the solid phase. Antibody density increases from $A$ to $D$. Increasing antibody density favors the ends-on immobilization which results in different exposure of the antibody binding sites. 

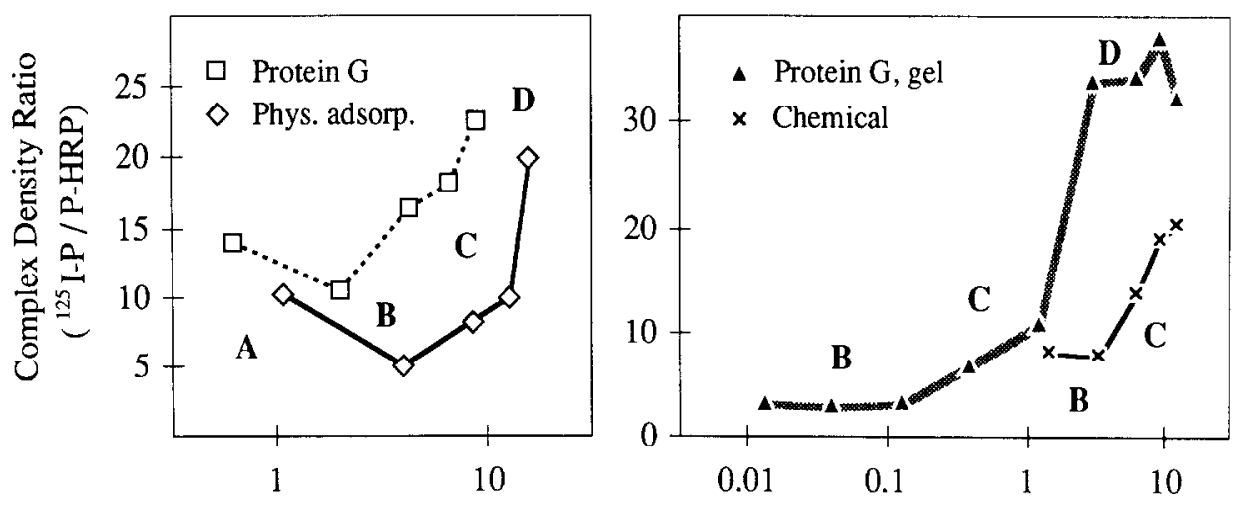

Antibody density $\left[\mathrm{fmol} / \mathrm{mm}^{2}\right]$

FIG. 5. Ratio of maximal complex densities (large antigen-antibody/small antigen-antibody) with antibody immobilized by different methods. The letters represent different stages of antibody density (and binding site exposure) as shown in Fig. 4.

presence of excess gelatin, gelatin occupies active sites on the matrix surface, thus preventing lipophilic interaction of the antibody with the surface and contributing to the favorable exposure of antibody binding sites of the IgG molecules.

Intermediate antibody density, Stage $C$. With a further increase in antibody density, the monolayer becomes more organized and a larger number of IgG molecules are immobilized in the ends-on configuration (i.e., via the $F_{c}$ region; Fig. 4 C) $(15,16,24)$. Now the larger number of IgG molecules prevents lateral access of the antigen to the antibody binding sites. The small antigen is less sterically hindered and as a result, the ratio small/large antigen complex increases (Fig. 5C). A similar model was recently suggested by Matson and Little (3) and other authors have mentioned before that the antibody density on the surface influences the formation of antibody-antigen complexes $(14,25)$.

High antibody density, Stage $D$. As the packing of IgG molecules on the surface gets tighter, fewer P-HRP antigens find accessible binding sites, which is expressed in the rising ratio ${ }^{125} \mathrm{I}-\mathrm{P} / \mathrm{P}-\mathrm{HRP}$. Eventually, the highest density reflecting a monolayer of IgG is formed (Fig. 4D) and the ratio of antibody-antigen complex for the two antigens approaches an asymptotic value (Fig. 5 , right).

Cluster (patch) formation. In all experiments, regardless of immobilization method, the large antigen, P-HRP, does not find easy access to the paratopes at antibody density $>12 \mathrm{fmol} / \mathrm{mm}^{2}$. This is expressed in the elevated ratio of the maximal complex density in favor of ${ }^{125}$ I-P (Fig. 5). At this antibody density, however, maximal packing of IgG molecules on the surface has not been attained (Fig. 1). If the antibody molecules are randomly distributed on the surface, there should be sufficient space for the $\mathrm{P}-\mathrm{HRP}$ conjugate to gain lateral access to the binding sites. We interpret these results as an indication that IgG occupies the surface in clusters or patches. The size of these patches increases when incubated with increasing concentrations of antibody until all of the surface is covered (Fig. 1).

The results of our experiments provide support for the hypothesis of cluster formation but final proof would have to be provided by an independent physical method [e.g., by channeling electron microscopy (26)]. It is likely that protein $G$ is distributed as an uniform monomolecular layer on the surface (excess of protein $G$ was used for the adsorption). Therefore, it appears that antibodies also bind to immobilized protein $G$ in clusters (Fig. 5).

If antibody is bound to protein $\mathrm{G}$ (both in the presence and absence of gelatin), "crowding" of P-HRP conjugate for binding occurs even at lower antibody density than for both the physical and chemical immobilization of IgG (Fig. 5 , the complex density ratios start to rise for protein $\mathrm{G}$ before the physical and chemical immobilization). Therefore, it seems that clusters of antibodies form with all the different methods of immobilization: physical adsorption, chemical binding to the modified surface, and even if the antibody is immobilized via protein G. It appears that cluster formation is not caused by surface properties but by the properties of the immunoglobulin itself (e.g., lipophilic or charge interactions).

The model described follows largely Kricka's suggestion of the transition from random to organized monolayer (24): "At low protein concentrations, protein adsorbs randomly across the surface of the adsorbent. An increase in the protein concentration causes a transition to a cooperative adsorption mode, which leads to a highly ordered, 'close packed' monolayer - a two dimensional crystal. . . ."

In designing immunoassays, we want to avoid interaction of the $F_{\text {ab }}$ region of IgG with the surface of the solid matrix (steric hindrance) and prefer, therefore, ends-on immobilization that is achieved at higher anti- 


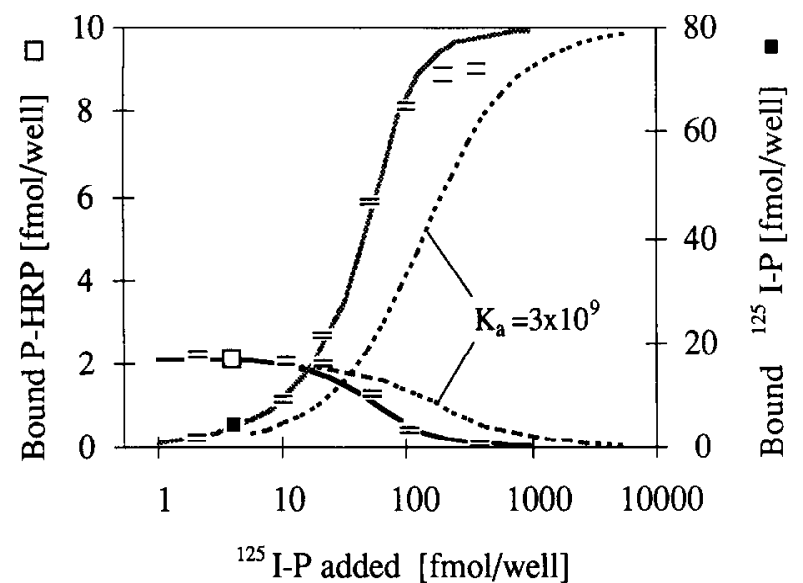

FIG. 6. Competitive binding between small and large labeled antigen. Immobilized antibody (via protein $\mathrm{G}$ in the presence of gelatin, $\left.\mathrm{P}-\mathrm{Ab}=0.32 \mathrm{fmol} / \mathrm{mm}^{2}\right)$ was coincubated with P $\mathrm{HRP}\left(K_{\mathrm{a}}=2.4 \times 10^{9}\right.$ liter $/ \mathrm{mol})$ and increasing amounts of ${ }^{125} \mathrm{I}-\mathrm{P}\left(K_{a}=3.3 \times 10^{10} \mathrm{liter} /\right.$ $\mathrm{mol}$ ). The solid lines represent data from mathematical modeling, the data points show experimentally obtained results (SD of triplicates). For comparison, displacement and complex formation with a small and a large antigen with the same binding constants are shown (stippled curves).

body densities. However, a different kind of steric hindrance may be introduced by packing the antibody molecules too densely. Where the optimum for accessibility lies depends on the size of the antigen and on the immobilization procedure.

\section{Competitive Binding between Large and Small Antigens}

While an immunoassay can be empirically optimized, we will introduce a model that can be used to predict the performance of assays using tracers of different size. This model will take into consideration not only the different binding constants between the antibody and the antigens, but also the different number of binding sites available to the antigens.

Available binding sites. For purposes of modeling, we can distinguish between two qualitatively different binding sites of the immobilized antibody: the large antigen, $P_{1}$, binds to one population of antibody binding sites, $\mathrm{Ab}$; the smaller antigen, $\mathrm{P}_{2}$, binds to $\mathrm{Ab}$ and to the binding sites that are not available to the large antigen, $\mathrm{Ab}^{\prime}$. According to the law of mass action, we have three equilibrium equations with two binding constants, $K_{a 1}$ and $K_{a 2}$ :

$$
\begin{gathered}
\mathrm{Ab}+\mathrm{P}_{1} \stackrel{K_{a 1}}{\longleftrightarrow} \mathrm{Ab}: \mathrm{P}_{1} \\
\mathrm{Ab}+\mathrm{P}_{2} \stackrel{K_{a 2}}{\longleftrightarrow} \mathrm{Ab}: \mathrm{P}_{2} \\
\mathrm{Ab}^{\prime}+\mathrm{P}_{2} \stackrel{K_{a 2}}{\longleftrightarrow} \mathrm{Ab}^{\prime}: \mathrm{P}_{2} .
\end{gathered}
$$

From the equilibrium reactions [1-3], three equations can be derived. Since these contain seven unknown vari- ables [concentrations of two unoccupied binding sites $\left(\mathrm{Ab}, \mathrm{Ab}^{\prime}\right)$, two unbound antigen species $\left(\mathrm{P}_{1}, \mathrm{P}_{2}\right)$, and three different binding complexes], four additional equations are supplemented from the law of mass action for $\mathrm{Ab}, \mathrm{Ab}^{\prime}, \mathrm{P}_{1}$, and $\mathrm{P}_{2}$. Scatchard analysis does not reveal any difference in the affinities of the two binding complexes $\mathrm{Ab}: \mathrm{P}_{2}$ and $\mathrm{Ab} \mathrm{b}^{\prime}: \mathrm{P}_{2}$; therefore, we use the same binding constant.

Using this model, $\mathrm{P}-\mathrm{HRP}\left(\mathrm{P}_{1}\right)$ is bound to immobilized antibody and we want to calculate the diminishing concentration of binding complex $\left[\mathrm{Ab}: \mathrm{P}_{1}\right]$ after adding increasing amounts of ${ }^{125} \mathrm{I}-\mathrm{P}\left(\mathrm{P}_{2}\right)$. To this end, we express the total concentration of the small antigen, $\left[\mathrm{P}_{2}\right]_{t}$, as

$$
\left[\mathrm{P}_{2}\right]_{t}=\left[\mathrm{P}_{2}\right]+\left[\mathrm{Ab}: \mathrm{P}_{2}\right]+\left[\mathrm{Ab}^{\prime}: \mathrm{P}_{2}\right]
$$

where we substitute the densities of the two binding complexes with the expressions

$$
\begin{aligned}
{\left[\mathrm{Ab}: \mathrm{P}_{2}\right] } & =\frac{[\mathrm{Ab}]_{t} K_{a 2}\left[\mathrm{P}_{2}\right]}{1+K_{a 1}\left[\mathrm{P}_{1}\right]+K_{a 2}\left[\mathrm{P}_{2}\right]} \\
{\left[\mathrm{Ab}^{\prime}: \mathrm{P}_{2}\right] } & =\frac{\left[\mathrm{Ab}^{\prime}\right]_{t} K_{a 2}\left[\mathrm{P}_{2}\right]}{1+K_{a 2}\left[\mathrm{P}_{2}\right]}
\end{aligned}
$$

and replace $\left[P_{2}\right]$ in $[4-6]$ with

$$
\left[\mathrm{P}_{2}\right]=\frac{1}{K_{a 2}}\left(\frac{[\mathrm{Ab}]_{t} K_{a 1}\left[\mathrm{P}_{1}\right]}{\left[\mathrm{Ab}: \mathrm{P}_{1}\right]}-K_{a 1}\left[\mathrm{P}_{1}\right]-1\right) .
$$

In Eqs. [5] and [7], $\left[\mathrm{P}_{1}\right]$ is substituted with

$$
\left[\mathrm{P}_{1}\right]=\left[\mathrm{P}_{1}\right]_{t}-\left[\mathrm{Ab}: \mathrm{P}_{1}\right]
$$

We can then express Eq. [4] as a function of only one variable, the binding complex $\left[\mathrm{Ab}: \mathrm{P}_{1}\right]$. The final formula is nonlinear and difficult to solve analytically. Therefore, we calculate $\left[A b: P_{1}\right]$ by a numerical method [e.g., Newton method (27)] after normalizing all dependent variables to the total concentration of the small antigen, $\left[\mathrm{P}_{2}\right]_{t}$. All the remaining variables in Eqs. [4-7] can then be determined from the calculated complex density $\left[\mathrm{Ab}: \mathrm{P}_{1}\right]$.

We have tested this model by coincubating a constant amount of analyte-enzyme conjugate with increasing amounts of radiolabeled tracer and we measured both signals, $\gamma$-radiation, and enzyme activity. The competitive binding of $\mathrm{P}-\mathrm{HRP}$ with ${ }^{125} \mathrm{I}-\mathrm{P}$ is shown in Fig. 6 . We observed good agreement between the model and the experimental results. The antibody can take up about the 10 -fold amount of the small antigen (Fig. 6, right scale) before P-HRP (left scale) starts to be displaced from the sites accessible to this larger antigen. The 


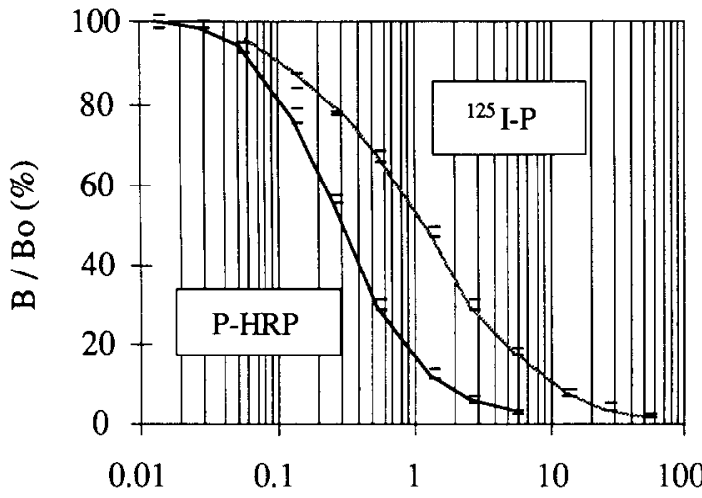

Progesterone [pmol/well]

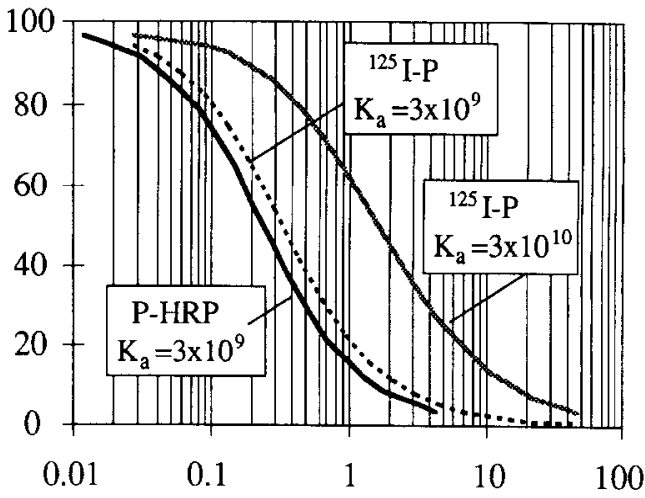

Progesterone [pmol/well]

FIG. 7. Left, dose-response curves with an antibody immobilized (via protein $\mathrm{G}$ in the presence of gelatin, $\mathrm{P}-\mathrm{Ab}=0.32 \mathrm{fmol} / \mathrm{mm}^{2}$ ) with ${ }^{125} \mathrm{I}-\mathrm{P}\left(K_{a}=3.3 \times 10^{10} \mathrm{liter} / \mathrm{mol}\right)$ and P-HRP $\left(K_{a}=2.4 \times 10^{9} \mathrm{liter} / \mathrm{mol}\right)$ as tracers (SD of triplicates). Right, an ${ }^{125} \mathrm{I}-\mathrm{P}$ derivative with the same $K_{a}$ as P-HRP shifts the dose-response curve close to that of P-HRP (calculated according to Eqs. [4-9]), despite of the larger number of accessible binding sites with the immobilized antibody (see Fig. 6).

complex density with ${ }^{125} \mathrm{I}-\mathrm{P}$ was finally about 35 -times higher than with $\mathrm{P}-\mathrm{HRP}$. The difference in complex formation cannot be attributed to the binding constants of the antigens (Fig. 6, stippled curves).

Dose-response curves. The sensitivity of dose-response curves is more affected by the binding constants of the antigens than by the number of available binding sites for complex formation. Using the same molar amount of antigen, the curve with ${ }^{125} \mathrm{I}-\mathrm{P}$ as tracer with a binding constant about 10 -fold higher than $\mathrm{P}-\mathrm{HRP}$ is in a less sensitive range ( $\mathrm{Fig}$. 7 , left). If we calculate the dose-response curve for an ${ }^{125} \mathrm{I}-\mathrm{P}$ derivative with the same binding constant as $\mathrm{P}-\mathrm{HRP}$, the positions of these curves are in close proximity (Fig. 7 , right).

Signal yield. The size of the labeled antigen determines the number of molecules in the immunoassay that can be utilized for signal generation. About three times as many molecules of the small antigen are bound if the binding constants of the two antigens are the same (Fig. 8). It should be recognized that for this example, the signal of the smaller antigen is of completely different nature (i.e., radiation) than the larger antigen (catalytic activity) and they cannot be directly compared. Likewise, in comparing analyte-enzyme conjugates, the turnover rate of different enzymes and their stability will affect the signal yield.

The sensitivity of competitive immunoassays depends, first, on the affinity constants between the antigens (i.e., native and labeled antigen) and the antibody (28). The higher the affinity constant, the less antibody is required. Second, the affinity constant of the labeled antigen can substantially affect the sensitivity (29). The more easily the labeled tracer is displaced, the less native antigen is required. A third component can attribute to higher sensitivity: the signal-to-noise ratio. If a labeled antigen can be used in a lower concentration because it is more efficiently used for complex formation (e.g., with smaller tracers), a more favorable signalto-noise ratio results.

\section{CONCLUSIONS}

The optimal performance of solid-phase enzyme immunoassays is determined by several interacting factors.

(a) The maximal number of antibody-antigen complexes formed with immobilized antibody is inversely proportional to the size of the antigen; i.e., an epitope that is part of a larger molecule binds to the same para-

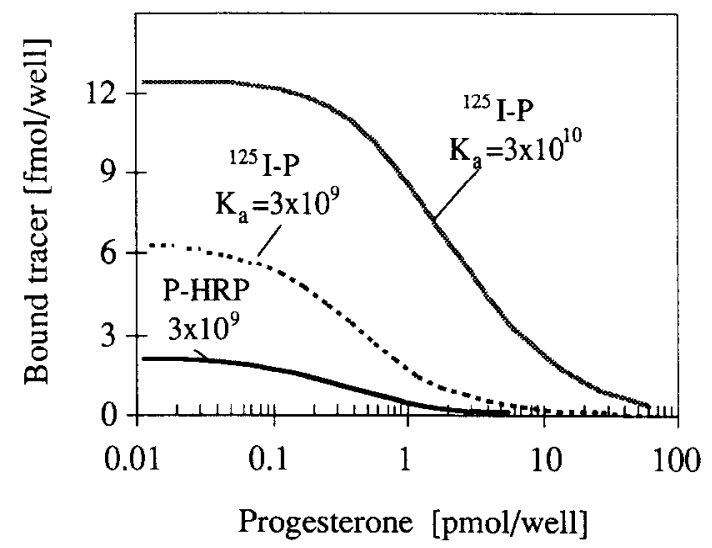

FIG. 8. The calculated amount of tracer bound at different analyte concentrations with immobilized antibody as described in the legend to Fig. 7 . The binding constants are shown in liter $/ \mathrm{mol}$. Besides the binding constant, the size of the labeled antigen also determines how much tracer is available for signal generation. 
tope of immunoglobulins to a lesser extent than the same epitope that is part of a smaller molecule.

(b) The difference in antibody-antigen complex density when small and relatively large antigens are used is also dependent on immobilized antibody density.

(c) In addition to (a) and (b), the ratio of accessible binding sites for complex formation and total binding depends on the immobilization method.

We have investigated these interdependent variables in one system. The results permitted us to propose a model for antibody immobilization and antibody-antigen complex formation with immobilized antibodies. The decision for selecting parameters will always depend on the specific analytical problem to be solved (e.g., expected analyte concentration, available specimen volume, desired signal yield, dynamic range, and others). Since these can vary substantially, preferred conditions for one application may not be the same for another. However, instead of using the empiric approach of trial and error for optimizing an immunoassay, the proposed model can be used to make some performance predictions for the design of immunoassays.

\section{ACKNOWLEDGMENTS}

This project was supported by grants from the National Institute of Health, R43 HD222316, R43 AI 24638, and the U.S. Army Research Office. The investigations were supported by many suggestions from and critical discussion with Drs. Paul A. Craig and Richard H. Smith and Robert L. Montgomery.

\section{REFERENCES}

1. Paek, S. H., and Schramm, W. (1991) Anal. Biochem. 196, 319325.

2. Schramm, W., and Paek, S. H. (1991) Anal. Biochem. 196, 326336.

3. Matson, R. S., and Little, M. C. (1988) J. Chromatogr. 458, 6777.

4. Björck, L., and Kronwall, G. (1984) J. Immunol. 133, 969-974.

5. Schramm, W., Yang, T., and Midgley, A. R. (1987) Clin. Chem. 33, 1331-1337.
6. Takacs, B. (1979) in Immunological Methods (Lefkovits, I., and Pernis, B., Eds.), pp. 81-105, Academic Press, New York.

7. Schramm, W., Yang, T., and Midgley, A. R. (1987) Clin. Chem. 33, 1338-1342.

8. Sanderson, C. J., and Wilson, D. V. (1971) Immunolngy 20, $1061-$ 1065.

9. Scatchard, G. (1949) Ann. N.Y. Acad. Sci. 51, 660-672.

10. Bos, E. S., van der Doelen, A. A., van Rooy, N., and Schuurs, A. H. (1981) J. Immunoassay 2, 187-204.

11. Zettner, A. (1973) Clin. Chem. 19, 699-705.

12. Steiner, H., and Dunford, H. B. (1978) Eur. J. Biochem. 82, 543549.

13. Walsh, J., and Gosling, J. P. (1986) Anal. Biochem. 413-423.

14. Cantarero, L. A., Butler, J. E., and Osborne, J. W. (1980) Anal. Biochem. 105, 375-382.

15. Bagchi, P., and Birnbaum, S. M. (1981) J. Colloid Interface Sci. 83, $460-478$.

16. Fair, B. D., and Jamieson, A. M. (1980) J. Colloid Interface Sci. 77, 525-534.

17. Baszkin, A., and Lyman, D. J. (1980) J. Biomed. Mater. Res. 14, 393-403.

18. Pachman, K., and Leibold, W. (1976) J. Immunol. Methods 12, 81-89.

19. Gabrilovac, J., Pachmann, K., Rodt, H., Jäger, G., and Thierfelder, S. (1979) J. Immunol. Methods 30, 161-170.

20. Lin, J.-N., Herron, J., Andrade, J. D., and Brizgys, M. (1988) IDEEE Trans. Biomed. Engin. 35, 466-471.

21. Alarie, J. P., Sepaniak, M. J., and Tuan, V.-D. (1990) Anal. Chim. Acta 229, 169-176.

22. Pilz, I., Kratky, O., and Karush, F. (1974) Eur. J. Biochem. 41, 91-96.

23. Green, N. M. (1969) Adv. Immunol. 11, 1-30.

24. Kricka, L. J. (1985) Ligand-Binder Assays: Labels and Analytical Strategies, pp. 76-95, Dekker, New York.

25. Salonen, E. M., and Vaheri, A. (1979) J. Immunol. Methods 30, 209-218.

26. Smith, D. P. E., Hörber, H., Gerber, C., and Binnig, G. (1989) Science 245, 43-45.

27. Kuo, S. (1972) Computer Applications of Numerical Methods, pp. 109-115, Addison-Wesley, Reading, MA.

28. Jackson, T. M., and Ekins, R. P. (1986) J. Immunol. Methods 87, $13-20$.

29. Bachas, L. G., and Meyerhoff, M. E. (1986) Anal. Biochem. 156, 223-238. 